$\begin{array}{ll}\text { Research Square } & \begin{array}{l}\text { Preprints are preliminary reports that have not undergone peer review. } \\ \text { They should not be considered conclusive, used to inform clinical practice, } \\ \text { or referenced by the media as validated information. }\end{array}\end{array}$

\title{
Diagnostic performance of clinic and home blood pressure measurements compared with ambulatory blood pressure: a systematic review and meta- analysis
}

Thunyarat Anothaisintawee ( $\nabla$ thunyarat.ano@mahidol.ac.th )

Mahidol University Faculty of Medicine Ramathibodi Hospital https://orcid.org/0000-0003-1002-8536

Auttakiat Kamjanapiboonwong

Mahidol University

Usa Chaikledkaew

Mahidol University

Charungthai Dejthevapom

Mahidol University Faculty of Medicine Ramathibodi Hospital

John Attia

The University of Newcastle - Newcastle City Campus

Ammarin Thakkinstian

Mahidol University Faculty of Medicine Ramathibodi Hospital

Research article

Keywords: clinic blood pressure measurement, home blood pressure measurement, diagnostic performance, hypertension, systematic review, meta-analysis

Posted Date: October 7th, 2019

DOI: https://doi.org/10.21203/rs.2.15646/v1

License: (c) (i) This work is licensed under a Creative Commons Attribution 4.0 International License. Read Full License

Version of Record: A version of this preprint was published at BMC Cardiovascular Disorders on November 23rd, 2020. See the published version at https://doi.org/10.1186/s12872-020-01736-2. 


\section{Abstract}

Background This systematic review aimed to estimate the performance of clinic(CBPM) and home blood pressure measurements(HBPM) compared with ambulatory blood pressure measurement(ABPM) and to pool prevalence of white coat and masked hypertension.

Methods Medline and Scopus databases were searched up to 11th June 2018. Studies having diagnostic test as CBPM or HBPM, reference standard as ABPM, and reported sensitivity and specificity of either or both tests and/or proportion of white coat or masked hypertension were eligible. Diagnostic performance of CBPM and HBPM were pooled using bivariate mixed-effect regression model. Random effect model was applied to pool prevalence of white coat and masked hypertension.

Results Forty-six studies were eligible. Pooled sensitivity, specificity, and diagnostic odds ratio of CBPM were 66\%(95\%Cl:58\%-73\%), 83\%(95\%Cl:75\%-89\%), and 9.75(95\%Cl:6.45-14.74), respectively. Pooled prevalence of white coat and masked hypertension were 31\%(95\%Cl:26\%-35\%) and 25\%(95\%Cl:22\%-28\%). Pooled sensitivity, specificity, and diagnostic odds ratio of HBPM were $71 \%(95 \% \mathrm{Cl}: 58 \%-80 \%), 84 \%(95 \% \mathrm{Cl}: 73 \%-91 \%)$, and 12.47(95\%Cl:6.13-25.37), respectively. Pooled prevalence of white coat and masked hypertension were $19 \%(95 \% \mathrm{Cl}: 10 \%-27 \%)$ and $31 \%(95 \% \mathrm{Cl}: 10 \%-52 \%)$.

Conclusions Diagnostic performances of HBPM were slightly higher than performance of CBPM. However, prevalence of masked hypertension was high in both negative CBPM and HBPM. Therefore, ABPM is still necessary for hypertension diagnosis, especially in people suspected with masked hypertension.

\section{Background}

Screening for hypertension (HT) is an important strategy for cardiovascular diseases (CVD) prevention. Currently, several approaches have been used for measuring blood pressure(BP) including ambulatory, home, and clinic blood pressure measurements(ABPM, HBPM, CBPM), that CBPM is the most commonly used in a routine clinical practice. However, patients may falsely have high BP only in the clinical setting, i.e., a phenomenon known as white coat hypertension(WCHT), while masked hypertension (MHT) is defined as normal BP in the clinic but an elevated BP measured by ABPM(1). The effect of WCHT on risk of CVD is slightly higher than normotension(2,3), whereas MHT is obviously harmful(4). Therefore, patients with WCHT receive unnecessary treatments whereas patients with $\mathrm{MHT}$ receive delayed proper treatments. Therefore, accurate diagnosis of $\mathrm{HT}$ is very important in order to prevent complications of HT and avoid unnecessary treatment. Guidelines by European Society of Cardiology and the European Society of Hypertension (ESH) 2018(5), and American Heart Association (AHA) 2017(1) suggest using ABPM as the reference standard for HT diagnosis. However, ABPM is not practical for routine use in clinical practice because of its high cost and poor patient compliance. HBPM is less expensive and more convenient than ABPM, therefore it has been suggested as an alternative for diagnosis of WCHT and or MHT(6). However, the performance of HBPM as the gold standard for HT diagnosis has still been uncertain(7).

To date, only one meta-analysis(8) in 2011 assessed the diagnostic performance of CBPM $(\mathrm{N}=7)$ and HBPM $(\mathrm{N}=3)$ using day-time ABPM as the reference standard. Overall sensitivity of CBPM was lower than HBPM (74.6\% vs. $85.7 \%)$, but the specificity was higher (74.6\% vs. $62.4 \%)$. Many individual studies for CBPM and few for HBPM have been published since then. Furthermore, some factors such as age, sex, measurement technique, and types of ABPM were highly associated with HT diagnosis(9-11), a subgroup analysis by these factors may be useful to guide BP screening strategy. Therefore, this systematic review was conducted with following aims: 1) update the diagnostic performances of CBPM and HBPM using ABPM as the standard test and, 2) pool prevalence of WCHT among positive CBPM and HBPM, and prevalence of MHT among negative CBPM and HBPM, 3) performing subgroup analysis by those potential factors associated with HT diagnosis. Results from this study will be useful for guiding primary care, internal medicine doctors, and cardiologists about the proper measurements used for diagnosis of HT.

\section{Methods}

\section{Selection of studies}

Relevant studies were identified from Medline and Scopus databases up to $11^{\text {th }}$ June 2018 using search terms and strategies described in the Additional Appendix. Reference lists of the included studies were searched to identify additional studies.

Studies were selected based on titles and abstracts; full articles were retrieved if more information was needed. The studies were eligible, if they include participants as adults aged $\geq 18$ years, had diagnostic test as CBPM or HBPM, reference standard as ABPM and reported sensitivity and specificity and/or WCHT proportion among CBPM/HBPM positive or MHT proportion among CBPM/HBPM negative.

\section{Study and standard tests}

The study tests were CBPM and HBPM. CBPM was performed in a health care setting, whereas HBPM was self-performed in a household using manual or automatic sphygmomanometers. Thresholds used for defining HT were BP $\geq 140 / 90 \mathrm{mmHg}$ for $\mathrm{CBPM}$ and $\mathrm{BP} \geq 130 / 80$ or $135 / 85 \mathrm{mmHg}$ for $\mathrm{HBPM}(12-14)$. The reference standard test was ABPM, a continuously measured BP in day-time (10-16 hours), night-time (6 hours), or 24 hours.

\section{Outcome of interest}


The interested outcome was HT diagnosed by ABPM using the thresholds of individual studies, which were 135/85, 120/70, and 130/80 mmHg for daytime/awake, night-time, and 24-hr, respectively. Diagnostic characteristics of CBPM and HBPM were estimated including sensitivity (i.e. proportion of positive CBPM/HBPM in HT group) and specificity (i.e. proportion of negative test in non-HT group). WCHT was defined as normal BP measured by ABPM among CBPM/HBPM positive whereas MHT was defined as high BP by ABPM among CBPM/HBPM negative(15).

\section{Data extraction}

Data were extracted including study's characteristics (i.e. study setting, study design), study participants (i.e. mean age, percent male, and underlying disease), study and standard tests (i.e. types, measurement device, time and duration of measurement, and cut-offs for HT diagnosis). Numbers of true positive, false positive, true negative, and false negative for each diagnostic test were extracted.

\section{Risk of bias assessment}

Risk of bias was assessed using the Quality of Diagnostic Accuracy Studies - 2 (QUADAS-2)(16) including domains of patient selection, index test, reference standard and flow/timing. Each domain consists of two sections, i.e., risk of bias and applicability. Risk of bias comprised 3 items (i.e., information used to support the risk of bias judgment, signaling questions, and judgment) which was judged as low, high, or unclear. Applicability was judged as low, unclear, or high risk according to whether the study did or did not match the review question.

\section{Statistical analysis}

Diagnostic performances of CBPM/HBPM versus ABPM (i.e., sensitivity, specificity, area under receiver operating characteristic(ROC) curve, likelihood ratio positive/negative $\left(\mathrm{LR}^{+} / \mathrm{LR}^{-}\right)$, and diagnostic odds ratio(DOR)) were estimated for individual studies. These were then pooled using a bivariate mixed-effect regression taking into account the different BP thresholds. In addition, the hierarchic summary ROC(HSROC) curve was estimated and plotted if applicable (number of studies $>4$ ); this was classified as low, moderate, and high accuracy if the HSROC were $0.5<x<0.7,0.7<x \leq 0.9$, and $0.9<x \leq 1$, respectively $(17)$.

Proportions of WCHT and MHT were separately pooled using a random-effect model if heterogeneity was present; otherwise a fixed-effect model was applied Heterogeneity was assessed using a $Q$ test $(p<0.1)$ and the $\mathrm{I}^{2}$ statistic $(>25 \%)$. Potential sources of heterogeneity (i.e. mean age, sex, study settings, types of ABPM, numbers of repeated BP measurement) were explored by adding variable one by one in a meta-regression model. If the variables could decrease $\mathrm{I}^{2}$ or tau $^{2}$, subgroup analysis was performed accordingly.

Publication bias was examined by Deek's funnel plot(18). If there was asymmetry, a contour-enhanced funnel plot was further explored to distinguish whether an asymmetrical funnel was due to heterogeneity or publication bias. All statistical analyses were performed with STATA version 15.0 (StataCorp, College Station, Texas). P-values $<0.05$ were considered statistically significant for all tests except for heterogeneity and Egger's tests, where a P-value $<0.10$ was used.

\section{Results}

Forty-six studies were eligible including $41(9,11,19-57), 2(58,59)$, and $3(7,60,61)$ assessing CBPM, HBPM, and both CBPM and HBPM, respectively (see Figure 1). Characteristics of these 46 studies are described in Table 1.

\section{Risk of bias assessment}

Results of risk of bias assessment are presented in Additional Table 1. All CBPM studies(7, 9, 11, 19-58, 60, 61) were low risk in all domains of applicability. $\operatorname{Ten}(20,26,31,38,39,44,50,52,57,58)$ and 6 studies $(30,34,41,46,49,55,59)$ were high and unclear bias in selection of study subjects. Forty three studies $(7,9,11,19-31,33-38,40-57,59-61)$ applied the index/study test before the reference standard but with unclear explanation of blinding. Thirty seven studies $(7,9,11,19-26,28-32,34,35,39,42,44-61)$ were high or unclear risk of bias in flows and timing because they did not report the time interval between the study test and the reference standard, or they also excluded subjects with invalid test results or those lost to follow up. All 5 HBPM studies(7, 5861) were low risk of bias in all domains of applicability whereas only $40 \%$ of them were relatively low. Three studies applied the index test before the reference standard without blinding information, and all studies were high risk of bias in their flow and timing.

\section{Pooling CBPM diagnostic performances}

Among 44 CBPM studies, 22 studies(7, 9, 11, 19-34, 40, 60, 61) reported $2 \times 2$ table data which could be assessed for diagnostic performance, while 7(35-39, $41,42)$ and 15(43-57) studies reported data for only positive and negative CBPM respectively (see Table 1).

Among the 22 studies, $21(7,9,11,20-34,40,61)$ and 1(19) studies used a cutoff threshold of $\geq 140 / 90$ and DBP > $95 \mathrm{mmHg}$ for diagnosis HT. The cut-offs of ABPM were 125-130/79-80 for 24-hr(11, 26, 31-33) and 135-140/85-91mmHg for day-time/awake(7, 19-25, 27-30, 34, 61). The mean age ranged from 39 to 61 years. Fifteen and 7 studies were community-based and healthcare-based, respectively (see Table 1). 
Data from 22 studies $(n=27,919)$ were used for pooling diagnostic characteristics of CBPM versus ABPM, see Additional Table 2 . The pooled sensitivity (95\% $\mathrm{Cl})$ and specificity $(95 \% \mathrm{Cl})$ were $66 \%\left(58 \%, 73 \% ; \mathrm{I}^{2}=97.65 \%\right)$ and $83 \%\left(75 \%, 89 \% ; I^{2}=98.23 \%\right)$ with high heterogeneity, see Figure 2 a-b. Pooled LR+ and LRwere $3.98\left(2.75,5.75 ; I^{2}=97.09 \%\right)$ and $0.41\left(0.34-0.49 ; I^{2}=96.27 \%\right)$, see Additional Figure 1 . These diagnostic characteristics all require setting a threshold and trading off sensitivity for specificity or LR+ for LR- hence they must be judged in pairs. For example, given a pretest probability of $\mathrm{HT}$ of $40 \%$, the post-test probability was increased to $73 \%$ if CBPM was positive, or reduced to $21 \%$ if CBPM was negative (see Fagan's plot Figure $3 a$ ). Alternatively, a single measure of diagnostic performance, i.e., the DOR was $9.75\left(6.45,14.74 ; I^{2}=100 \%\right)$, see Additional Figure $1 \mathrm{c}$. The HSROC reflects diagnostic performance across the entire range of possible threshold values; in this case, the pooled HSROC was $0.80(0.76,0.83)$ indicating moderately good discrimination for judging presence of HT (Additional Figure 2a). Deek's funnel plot shows no evidence of publication bias (Additional Figure 3a).

Subgroup analysis

Subgroup analyses were performed by types of ABPM, age group ( $<50$ and $\geq 50$ years), percent males ( $<50 \%$ and $\geq 50 \%$ ), number of repeated measurements of CBPM (1, 2-5 times), setting of studies (community and hospital-based), and type of patients (no HT, mixed HT with non-HT). The degrees of heterogeneity $\left(1^{2}\right)$ did not decrease for each sub-group of these factors (Additional Table 3) but performances of CBPM improved in some sub-groups including age group $\leq 50$ year, percent male $\leq 50 \%$, community-based setting, and 24-hr ABPM with the LR+ of $5.7(3.4,9.7), 6.7(3.6,12.4), 7.2(4.9,10.8)$ and $7.3(4.6,11.6)$, respectively.

\section{Pooling HBPM diagnostic performances}

Five HBPM studies(7, 58-61) reported 2x2 table data (Additional Table 4). Mean age and percent male ranged from 48.1 to 51.8 years and $46.5 \%$ to $54.9 \%$ respectively. Three and 1 studies used HBPM cut-offs of $135 / 85 \mathrm{mmHg}$ and $140 / 90 \mathrm{mmHg}$ respectively, with measurement duration about 5 to 7 days, see Table 1. Two, 2, and 1 studies applied 24-hr ABPM, day or awake ABPM, and multiple periods respectively.

The overall pooled sensitivity and specificity were respectively $71 \%\left(58 \%, 80 \% ; I^{2}=92.40 \%\right)$ and $84 \%\left(73 \%, 91 \% ; I^{2}=91.79 \%\right)$, see Figures $2 \mathrm{c}$-d. The pooled DOR, LR+ and LR-were $13\left(6,25 ; I^{2}=99.99 \%\right), 4.4\left(2.6,7.4 ; I^{2}=84.38 \%\right)$, and $0.35\left(0.25,0.50 ; I^{2}=90.18 \%\right)$, see Additional Figure 4 a-c. Again, given a pretestprobability of $40 \%$, a positive result on HBPM would result in a post-test probability of $74 \%$, while a negative result on HBPM would reduce the probability to $19 \%$ (Figure $3 b)$. The pooled HSROC was $0.84(0.80,0.87)$, again suggesting moderately good discrimination for HBPM, see Additional Figure $2 \mathrm{~b}$. Sub-group analysis could not be performed due to the small number of included studies. Deek's funnel plot indicated no evidence of publication bias, see Additional Figure 3b.

\section{Pooling prevalence of WCHT and MHT by CBPM}

Seven $(35-39,41,42)$ and 15 studies(43-57) reported only data of WCHT and MHT, see Table 1 . These studies were then combined with CBPM studies reporting $2 \times 2$ data above, yielding a total of 29 and 37 studies for pooling proportions of WCHT and MHT respectively.

Among the 29 studies pooling WCHT, time of ABPM measures were 24-hr $(\mathrm{N}=7)$, day-time/awake $(\mathrm{N}=20)$, and multiple periods ( $\mathrm{N}=2)$. Among the 37 studies pooling MHT, ABPM measures were $24-\mathrm{hr}(\mathrm{N}=7)$, day-time/awake $(\mathrm{N}=18)$, and multiple times $(\mathrm{N}=7)$, both 24 -hr and daytime $(\mathrm{N}=4)$, and daytime and nighttime $(\mathrm{N}=1)$.

Data for the $29(n=10458)$ and $37(n=30344)$ studies for WCHT and MHT are provided in Additional Tables 5 and 6 . The pooled proportions of WCHT and MHT were $0.31(0.26,0.35)$ and $0.25(0.22,0.28)$ with corresponding $I^{2}$ of $96.66 \%$ and $97.80 \%$ respectively, see Figures $4 a$ and $4 b$.

Subgroup analyses were performed but none of co-variables could decrease the degree of heterogeneity (see Additional Table 7). However, subgroup of repeated measures of CBPM 4-5 times and 24-hr ABPM could respectively reduce the pooled WCHT from 31\% to $23 \%$ (16\%, 31\%) and $22 \%$ (13\%, 30\%). Likewise, repeated CBPM measure could reduce the pooled MHT from 25\% to 15\% (10\%, 19\%) whereas the 24 -hr ABPM conversely increased the prevalence to $31 \%(22 \%, 40 \%)$.

\section{Pooling prevalence of WCHT and MHT by HBPM}

Five HBPM studies were included for pooling WCHT $(n=726)$ and MHT $(n=1064)$, see Additional Table 4. The pooled prevalence of WCHT and MHT were $0.19(0.10,0.27)$ and $0.31(0.10,0.52)$ with the corresponding $\mathrm{I}^{2}$ of $88.65 \%$ and $98.24 \%$, see Figures $4 \mathrm{c}-\mathrm{d}$.

\section{Discussion}

The results from our study suggest that diagnostic performances of HBPM were slightly higher than those of CBPM. The pooled sensitivity, specificity, DOR, $\mathrm{LR}+$, and area under ROC for CBPM were respectively $66 \%, 83 \%, 9.67,3.98$, and 0.80 , while these corresponding values for HBPM were $71 \%, 84 \%, 12,4.4$, and 0.84 , respectively.

To date, there has been only one systematic review published in 2011(8), which included fewer studies than ours (7 versus 22 for CBPM and 3 versus 5 for HBPM). Overall sensitivities of both CBPM ( $66 \%$ vs. $75 \%)$ and HBPM $(71 \%$ vs. $86 \%)$ found in our study were lower than the previous review, while the specificities of both CBPM (83\% vs. $75 \%)$ and HBPM were higher ( $84 \%$ vs. $62 \%)$. Our pooled estimates are more precise than the previous review, which was

Page 4/15 
limited by the small number of included studies. In addition, our results indicate that roughly $30 \%$ of those who are positive on CBPM may have WCHT and roughly $20 \%$ of those who are negative on CBPM may have MHT. The prevalence of WCHT and MHT were roughly reversed when using HBPM.

The percentage of WCHT was lowest when comparing CBPM with 24-hr ABPM (22\%), while the percentage of MHT was highest when comparing CBPM with 24-hr ABPM (31\%). This reinforces the belief that 24-hr ABPM yields the best for detecting HT because it can capture the nighttime and morning surge BP. Therefore, the actual WCHT in the clinical practice may be lower than the value found in our study(31\%), which most of the studies compared CBPM with daytime ABPM. The number of repeated measurements of CBPM also affected the diagnostic performances, i.e., there was a lower WCHT and MHT if repeatedly measuring CBPMs over 4-5 visits.

Our results also found that the percent WCHT was lower in HBPM than CBPM (19\% versus 31\%), in other words, a diagnosis of HT by CBPM alone could lead to misclassify patients who actually do not have hypertension. This is an important issue for diagnosis and treatment of hypertension because previous evidence from meta-analyses found a similar risk of cardiovascular disease between those with WCHT and normotension(62-64). Unnecessary treatments of WCHT have several disadvantages including potential adverse drug events and costs. Measuring BP in the patient's own environment using HBPM could reduce stress and decrease over-diagnosis of HT. Although HBPM could decrease WCHT, implementing HBPM for screening HT in the general population may carry significant budget implications, particularly in low and middle income countries.

An automated office blood pressure measurement (AOBPM), in which clinic BP is measured when patient is unattended sitting in a quiet room, might be alternative if ABPM cannot be applied as for evidences from the recent meta-analyses $(65,66)$. These evidences showed that BP measured by AOBPM was not different from BP measured by awake/daytime ABPM but it was significant different when compared to CBPM that measured by physicians or nurses. Therefore, the AOBPM may be another option to enhance diagnostic performance of CBPM in routine clinical practice.

In contrast to WCHT, detection of MHT is important for CVD prevention. Our results found that prevalence of MHT was high in both normal CBPM (25\%) and HBPM (31\%). Thus, ABPM is still necessarily for confirming the diagnosis of MHT. Nonetheless, screening all individuals with normal CBPM or HBPM is impractical; prioritizing people who are high risk of CVD to screen with ABPM is important. Several approaches have been used for identifying such high risk individuals. For instance, Veira et al(49) suggested that people with prehypertension by CBPM (systolic BP $=120-139 \mathrm{mmHg}$ and $/$ or diastolic $\mathrm{BP}=80-89$ $\mathrm{mmHg}$ ) should be referred for ABPM to screen MHT. However, the false positive rate of this approach was as high as $40 \%$ and the authors concluded that high-normal BP from CBPM alone might not be appropriate for prioritizing people to screen for MHT.

Another method is CVD risk-based approach using known CVD risk factors such as male sex, smoking, obesity, and diabetes. However, results from Colantonio et al. indicated that considering metabolic syndrome did not provide higher prediction of MHT than using clinic BP alone(67). Therefore, future research about the strategies to identify individual at high risk of MHT is needed.

Our study has some strengths. We estimated the diagnostic performance of CBPM and HBPM relative to ABPM by pooling data from 22 and 5 studies additional with prevalence of WCHT and MHT. However, our pooling was based on high heterogeneity, particularly for pooling WCHT and MHT without identified causes of heterogeneity. In addition, the number of studies addressing the diagnostic performance of HBPM were much lower than the number of studies addressing the performance of CBPM. Therefore, the comparison of diagnostic performance between CBPM and HBPM should be interpreted with caution. Moreover, due to the low number of the studies of HBPM, individual patient data (IPD) meta-analysis of diagnostic performance of HBPM should be considered to allow for more sub-group analysis of specific factors.

\section{Conclusion}

In conclusion, diagnostic performances of HBPM were slightly higher than the performance of CBPM. However, the prevalence of MHT was high in both negative HBPM and CBPM. Therefore, ABPM is still necessary for confirming the diagnosis of HT, especially in people who are highly suspected with MHT.

\section{Abbreviations}

ABPM; ambulatory blood pressure measurement, AHA; American Heart Association, BP; blood pressure, CBPM; clinic blood pressure measurement, Cl; confidence interval, CKD; chronic kidney disease, CVD; cardiovascular diseases, DBP; diastolic blood pressure, DM; diabetes mellitus, DOR; diagnostic odds ratio, HBPM; home blood pressure measurement, HT; hypertension, LR; likelihood ratio, MHT; masked hypertension, NM; normotension, QUADAS-2; Quality of Diagnostic Accuracy Studies-2, ROC; receiver operating characteristic, SBP; systolic blood pressure, SD; standard deviation, SE; standard error, WCHT; white coat hypertension

\section{Declarations}

Ethics approval and consent to participate: Not applicable

Consent for publication: Not applicable

Availability of data and materials: All data generated or analysed during this study are included in this published article and its Additional information files.

Competing interests: The authors declare that they have no competing interests.

Funding: This study had no funding support. 
Authors' contributions: AK, TA and AT were responsible for designing the study. AK and TA were responsible for searching the databases, selecting the studies, and extracting the data. AK, TA, and AT analyzed the data. AK and TA drafted the manuscript. CD, AT, UC, and JA critically revised the manuscript.

Acknowledgements: Not applicable

\section{References}

1.Whelton PK, Carey RM, Aronow WS, Casey DE, Jr., Collins KJ, Dennison Himmelfarb C, et al. 2017

ACC/AHA/AAPA/ABC/ACPM/AGS/APhA/ASH/ASPC/NMA/PCNA Guideline for the Prevention, Detection, Evaluation, and Management of High Blood Pressure in Adults: A Report of the American College of Cardiology/American Heart Association Task Force on Clinical Practice Guidelines. Hypertension (Dallas, Tex: 1979). 2018;71(6):e13-e115.

2.Briasoulis A, Androulakis E, Palla M, Papageorgiou N, Tousoulis D. White-coat hypertension and cardiovascular events: a meta-analysis. J Hypertens. 2016;34(4):593-9.

3.Huang Y, Huang W, Mai W, Cai X, An D, Liu Z, et al. White-coat hypertension is a risk factor for cardiovascular diseases and total mortality. J Hypertens. 2017;35(4):677-88.

4.Sikarin Upala AS. Risk of mortality and cardiovascular events in white coat hypertension: a systematic review and meta-analysis. journal of American society of hypertension. 2016;10(4):88.

5.Williams B, Mancia G, Spiering W, Agabiti Rosei E, Azizi M, Burnier M, et al. 2018 Practice Guidelines for the management of arterial hypertension of the European Society of Hypertension and the European Society of Cardiology: ESH/ESC Task Force for the Management of Arterial Hypertension. J Hypertens. 2018;36(12):2284-309.

6.Mallick S, Kanthety R, Rahman M. Home blood pressure monitoring in clinical practice: a review. Am J Med. 2009;122(9):803-10.

7.Stergiou GS, Skeva, II, Baibas NM, Kalkana CB, Roussias LG, Mountokalakis TD. Diagnosis of hypertension using home or ambulatory blood pressure monitoring: comparison with the conventional strategy based on repeated clinic blood pressure measurements. J Hypertens. 2000;18(12):1745-51.

8.Hodgkinson J, Mant J, Martin U, Guo B, Hobbs FD, Deeks JJ, et al. Relative effectiveness of clinic and home blood pressure monitoring compared with ambulatory blood pressure monitoring in diagnosis of hypertension: systematic review. BMJ. 2011;342:d3621.

9.Conen D, Aeschbacher S, Thijs L, Li Y, Boggia J, Asayama K, et al. Age-specific differences between conventional and ambulatory daytime blood pressure values. Hypertension (Dallas, Tex: 1979). 2014;64(5):1073-9.

10.Etyang AO, Warne B, Kapesa S, Munge K, Bauni E, Cruickshank JK, et al. Clinical and Epidemiological Implications of 24-Hour Ambulatory Blood Pressure Monitoring for the Diagnosis of Hypertension in Kenyan Adults: A Population-Based Study. J Am Heart Assoc. 2016;5(12).

11.Rhee MY, Kim SW, Choi EH, Kim JH, Nah DY, Shin SJ, et al. Prevalence of Masked Hypertension: a Population-Based Survey in a Large City by Using 24Hour Ambulatory Blood Pressure Monitoring. Korean Circ J. 2016;46(5):681-7.

12.Jaques H, National Institute for H, Clinical E. NICE guideline on hypertension. Eur Heart J. 2013;34(6):406-8.

13.Ritchie LD, Campbell NC, Murchie P. New NICE guidelines for hypertension. BMJ. 2011;343:d5644.

14.Dixon DL, Salgado TM, Caldas LM, Van Tassell BW, Sisson EM. The 2017 American College of Cardiology/American Heart Association hypertension guideline and opportunities for community pharmacists. J Am Pharm Assoc (2003). 2018.

15.de la Sierra A. Definition of white coat hypertension: ambulatory blood pressure, self-measured blood pressure, or both? Hypertension (Dallas, Tex: 1979). 2013;62(1):16-7.

16.Whiting PF, Rutjes AW, Westwood ME, Mallett S, Deeks JJ, Reitsma JB, et al. QUADAS-2: a revised tool for the quality assessment of diagnostic accuracy studies. Ann Intern Med. 2011;155(8):529-36.

17.Swets JA. Measuring the accuracy of diagnostic systems. Science. 1988;240(4857):1285-93.

18.Deeks JJ, Macaskill P, Irwig L. The performance of tests of publication bias and other sample size effects in systematic reviews of diagnostic test accuracy was assessed. Journal of clinical epidemiology. 2005;58(9):882-93.

19.Brueren MM, Dinant GJ, Schouten BJ, van Ree JW. [Hypertension diagnosis by the family physician: measurements according to the NHG-standard (Dutch College of General Practitioners) compared with ambulatory blood pressure determination]. Ned Tijdschr Geneeskd. 1995;139(6):278-82.

20.Botomino A, Martina B, Ruf D, Bruppacher R, Hersberger KE. White coat effect and white coat hypertension in community pharmacy practice. Blood pressure monitoring. 2005;10(1):13-8. 
21.Ungar A, Pepe G, Monami M, Lambertucci L, Torrini M, Baldasseroni S, et al. Isolated ambulatory hypertension is common in outpatients referred to a hypertension centre. Journal of human hypertension. 2004;18(12):897-903.

22.Ohkubo T, Kikuya M, Metoki H, Asayama K, Obara T, Hashimoto J, et al. Prognosis of "masked" hypertension and "white-coat" hypertension detected by 24h ambulatory blood pressure monitoring 10-year follow-up from the Ohasama study. J Am Coll Cardiol. 2005;46(3):508-15.

23.Fagard RH, Van Den Broeke C, De Cort P. Prognostic significance of blood pressure measured in the office, at home and during ambulatory monitoring in older patients in general practice. Journal of human hypertension. 2005;19(10):801-7.

24.Wang GL, Li Y, Staessen JA, Lu L, Wang JG. Anthropometric and lifestyle factors associated with white-coat, masked and sustained hypertension in a Chinese population. J Hypertens. 2007;25(12):2398-405.

25.Trudel X, Brisson C, Larocque B, Milot A. Masked hypertension: different blood pressure measurement methodology and risk factors in a working population. J Hypertens. 2009;27(8):1560-7.

26.Ishikawa J, Hoshide S, Eguchi K, Schwartz JE, Pickering TG, Shimada K, et al. Masked hypertension defined by ambulatory blood pressure monitoring is associated with an increased serum glucose level and urinary albumin-creatinine ratio. Journal of clinical hypertension (Greenwich, Conn). 2010;12(8):57887.

27.Maseko MJ, Woodiwiss AJ, Majane OH, Molebatsi N, Norton GR. Marked underestimation of blood pressure control with conventional vs. ambulatory measurements in an urban, developing community of African ancestry. American journal of hypertension. 2011;24(7):789-95.

28.Afsar B. Comparison of demographic, clinical, and laboratory parameters between patients with sustained normotension, white coat hypertension, masked hypertension, and sustained hypertension. Journal of cardiology. 2013;61(3):222-6.

29.Alwan H, Pruijm M, Ponte B, Ackermann D, Guessous I, Ehret G, et al. Epidemiology of masked and white-coat hypertension: the family-based SKIPOGH study. PloS one. 2014;9(3):e92522.

30.Al-Hashmi K, Al-Busaidi N, Amina B, Jaju D, Al-Waili K, Al-Rasadi K, et al. White coat hypertension and masked hypertension among omani patients attending a tertiary hospital for ambulatory blood pressure monitoring. Oman Med J. 2015;30(2):90-4.

31.Mutlu S, Sari O, Arslan E, Aydogan U, Doganer YC, Koc B. Comparison of ambulatory blood pressure measurement with home, office and pharmacy measurements: is arterial blood pressure measured at pharmacy reliable? Journal of evaluation in clinical practice. 2016;22(1):40-5.

32.Scuteri A, Morrell CH, Orru M, AIGhatrif M, Saba PS, Terracciano A, et al. Gender specific profiles of white coat and masked hypertension impacts on arterial structure and function in the SardiNIA study. International journal of cardiology. 2016;217:92-8.

33.Melgarejo JD, Maestre GE, Thijs L, Asayama K, Boggia J, Casiglia E, et al. Prevalence, Treatment, and Control Rates of Conventional and Ambulatory Hypertension Across 10 Populations in 3 Continents. Hypertension (Dallas, Tex: 1979). 2017;70(1):50-8.

34.Fujita H, Matsuoka S, Awazu M. Masked Isolated Nocturnal Hypertension in Children and Young Adults. Pediatric cardiology. 2018;39(1):66-70.

35. Hoegholm A, Kristensen KS, Bang LE, Gustavsen PH. White coat hypertension and blood pressure variability. American journal of hypertension. 1999;12(10 l):966-72.

36.Martinez MA, Garcia-Puig J, Martin JC, Guallar-Castillon P, Aguirre de Carcer A, Torre A, et al. Frequency and determinants of white coat hypertension in mild to moderate hypertension: a primary care-based study. Monitorizacion Ambulatoria de la Presion Arterial (MAPA)-Area 5 Working Group. American journal of hypertension. 1999;12(3):251-9.

37.Gan SK, Loh CY, Seet B. Hypertension in young adults-an under-estimated problem. Singapore medical journal. 2003;44(9):448-52.

38.Tunçkale A, Aran SN, Karpuz H, Dirican A. Relationship between insulin resistance and end-organ damage in white coat hypertension. American journal of hypertension. 2004;17(11):1011-6.

39.Shimbo D, Kuruvilla S, Haas D, Pickering TG, Schwartz JE, Gerin W. Preventing misdiagnosis of ambulatory hypertension: algorithm using office and home blood pressures. J Hypertens. 2009;27(9):1775-83.

40.Berge HM, Andersen TE, Solberg EE, Steine K. High ambulatory blood pressure in male professional football players. British journal of sports medicine. 2013;47(8):521-5.

41.Pengkeaw P, Suwannakarn S. Prevalence of hypertension in suspected hypertensive patients in Rajavithi Hospital using ambulatory blood pressure monitoring. Journal of the Medical Association of Thailand = Chotmaihet thangphaet. 2014;97 Suppl 11:S25-30.

42.Mancia G, Facchetti R, Grassi G, Bombelli M. Adverse prognostic value of persistent office blood pressure elevation in white coat hypertension. Hypertension (Dallas, Tex: 1979). 2015;66(2):437-44. 
43.Schoenthaler AM, Schwartz J, Cassells A, Tobin JN, Brondolo E. Daily interpersonal conflict predicts masked hypertension in an urban sample. American journal of hypertension. 2010;23(10):1082-8.

44.Viera AJ, Hinderliter AL, Kshirsagar AV, Fine J, Dominik R. Reproducibility of masked hypertension in adults with untreated borderline office blood pressure: comparison of ambulatory and home monitoring. American journal of hypertension. 2010;23(11):1190-7.

45.Bacaksiz A, Erdogan E, Sonmez O, Sevgili E, Tasal A, Onsun N, et al. Ambulatory blood pressure monitoring can unmask hypertension in patients with psoriasis vulgaris. Medical science monitor: international medical journal of experimental and clinical research. 2013;19:501-9.

46.Sobrino J, Domenech M, Camafort M, Vinyoles E, Coca A. Prevalence of masked hypertension and associated factors in normotensive healthcare workers. Blood pressure monitoring. 2013;18(6):326-31.

47.Franklin SS, Thijs L, Li Y, Hansen TW, Boggia J, Liu Y, et al. Masked hypertension in diabetes mellitus: treatment implications for clinical practice. Hypertension (Dallas, Tex: 1979). 2013;61(5):964-71.

48.Larsen TR, Gelaye A, Waanbah B, Assad H, Daloul Y, Williams F, et al. Prevalence of masked hypertension in African Americans. Journal of clinical hypertension (Greenwich, Conn). 2014;16(11):801-4.

49.Viera AJ, Lin FC, Tuttle LA, Shimbo D, Diaz KM, Olsson E, et al. Levels of office blood pressure and their operating characteristics for detecting masked hypertension based on ambulatory blood pressure monitoring. American journal of hypertension. 2015;28(1):42-9.

50.Trachsel LD, Carlen F, Brugger N, Seiler C, Wilhelm M. Masked hypertension and cardiac remodeling in middle-aged endurance athletes. J Hypertens. 2015;33(6):1276-83.

51.Redmond N, Booth JN, 3rd, Tanner RM, Diaz KM, Abdalla M, Sims M, et al. Prevalence of Masked Hypertension and Its Association With Subclinical Cardiovascular Disease in African Americans: Results From the Jackson Heart Study. J Am Heart Assoc. 2016;5(3):e002284.

52.Viera AJ, Lin FC, Tuttle LA, Olsson E, Girdler SS, Hinderliter AL. Examination of Several Physiological and Psychosocial Factors Potentially Associated With Masked Hypertension Among Low-Risk Adults. Journal of clinical hypertension (Greenwich, Conn). 2016;18(8):784-9.

53.Piantanida E, Gallo D, Veronesi G, Pariani N, Masiello E, Premoli P, et al. Masked hypertension in newly diagnosed hypothyroidism: a pilot study. Journal of endocrinological investigation. 2016;39(10):1131-8.

54.Booth JN, 3rd, Muntner P, Diaz KM, Viera AJ, Bello NA, Schwartz JE, et al. Evaluation of Criteria to Detect Masked Hypertension. Journal of clinical hypertension (Greenwich, Conn). 2016;18(11):1086-94.

55.Anstey DE, Booth JN, Abdalla M, Spruill TM, Min YI, Muntner P, et al. Predicted Atherosclerotic Cardiovascular Disease Risk and Masked Hypertension among Blacks in the Jackson Heart Study. Circulation: Cardiovascular Quality and Outcomes. 2017;10(7).

56.Ozkan S, Ata N, Yavuz B. Increased masked hypertension prevalence in patients with obesity. Clinical and experimental hypertension (New York, NY: 1993). 2018:1-4

57.Gun T, Ozkan S, Yavuz B. Is tinnitus an early voice of masked hypertension? High masked hypertension rate in patients with tinnitus. Clinical and experimental hypertension (New York, NY: 1993). 2018:1-4.

58.Almeida AE, Stein R, Gus M, Nascimento JA, Arevalo JR, Fuchs FD, et al. Improved diagnostic accuracy of a 3-day protocol of home blood pressure monitoring for the diagnosis of arterial hypertension. Blood pressure monitoring. 2013;18(2):119-26.

59.Park JS, Rhee MY, Namgung J, Lee SY, Cho DK, Choi TY, et al. Comparison of Optimal Diagnostic Thresholds of Hypertension With Home Blood Pressure Monitoring and 24-Hour Ambulatory Blood Pressure Monitoring. American journal of hypertension. 2017;30(12):1170-6.

60.Zhang L, Li Y, Wei FF, Thijs L, Kang YY, Wang S, et al. Strategies for classifying patients based on office, home, and ambulatory blood pressure measurement. Hypertension (Dallas, Tex: 1979). 2015;65(6):1258-65.

61. Hanninen MR, Niiranen TJ, Puukka PJ, Jula AM. Comparison of home and ambulatory blood pressure measurement in the diagnosis of masked hypertension. J Hypertens. 2010;28(4):709-14.

62.Franklin SS, Thijs L, Hansen TW, O'Brien E, Staessen JA. White-coat hypertension: new insights from recent studies. Hypertension (Dallas, Tex: 1979). 2013;62(6):982-7.

63.Verdecchia P, Reboldi GP, Angeli F, Schillaci G, Schwartz JE, Pickering TG, et al. Short- and long-term incidence of stroke in white-coat hypertension. Hypertension (Dallas, Tex: 1979). 2005;45(2):203-8.

64.Stergiou GS, Asayama K, Thijs L, Kollias A, Niiranen TJ, Hozawa A, et al. Prognosis of white-coat and masked hypertension: International Database of HOme blood pressure in relation to Cardiovascular Outcome. Hypertension (Dallas, Tex: 1979). 2014;63(4):675-82. 
65.Roerecke M, Kaczorowski J, Myers MG. Comparing Automated Office Blood Pressure Readings With Other Methods of Blood Pressure Measurement for Identifying Patients With Possible Hypertension: A Systematic Review and Meta-analysis. JAMA Intern Med. 2019.

66.Pappaccogli M, Di Monaco S, Perlo E, Burrello J, D’Ascenzo F, Veglio F, et al. Comparison of Automated Office Blood Pressure With Office and Out-Off-Office Measurement Techniques. Hypertension (Dallas, Tex: 1979). 2019;73(2):481-90.

67.Colantonio LD, Anstey DE, Carson AP, Ogedegbe G, Abdalla M, Sims M, et al. Metabolic syndrome and masked hypertension among African Americans: The Jackson Heart Study. Journal of clinical hypertension (Greenwich, Conn). 2017;19(6):592-600.

\section{Tables}

Table 1: Characteristic of included studies 


\begin{tabular}{|c|c|c|c|c|c|c|c|c|c|c|}
\hline $\begin{array}{l}\text { Author } \\
\text { (Year) }\end{array}$ & Country & Setting & $\begin{array}{c}\text { Type of } \\
\text { population }\end{array}$ & $\begin{array}{c}\text { Previous } \\
\text { HT }\end{array}$ & $\begin{array}{c}\text { Taking } \\
\text { anti-HT } \\
\text { drug }\end{array}$ & $\begin{array}{c}\text { Mean } \\
\text { age } \\
\text { (year) }\end{array}$ & \%Male & $\begin{array}{c}\text { CBPM; } \\
\text { HBPM } \\
\text { cut-off } \\
\text { (mmHg) }\end{array}$ & \begin{tabular}{c|} 
No. \\
repeated \\
measure \\
CBPM \\
(day \\
interval) \\
\end{tabular} & $\begin{array}{l}\text { Measurement } \\
\text { duration for } \\
\text { HBPM (day) }\end{array}$ \\
\hline \multicolumn{11}{|c|}{ Studies with complete $2 \times 2$ diagnostic results of CBPM only } \\
\hline $\begin{array}{l}\text { Brueren M. } \\
\text { 1995(19) }\end{array}$ & Netherland & $\begin{array}{l}\text { Health } \\
\text { care }\end{array}$ & Outpatient & Non-HT & No & 47 & 51.13 & 95(DBP) & $3(-)$ & - \\
\hline $\begin{array}{l}\text { Botomino A. } \\
2004(20)\end{array}$ & Switzerland & Community & $\begin{array}{l}\text { General } \\
\text { population }\end{array}$ & Mixed & Unspecified & 53.7 & 42 & $140 / 90$ & 1 & - \\
\hline $\begin{array}{l}\text { Ungar A } \\
2004(21)\end{array}$ & Italy & $\begin{array}{l}\text { Health } \\
\text { care }\end{array}$ & $\begin{array}{l}\text { General } \\
\text { population }\end{array}$ & Mixed & No & 60 & 48.8 & $140 / 90$ & 1 & - \\
\hline $\begin{array}{l}\text { Ohkubo T. } \\
\text { 2005(22) }\end{array}$ & Japan & Community & $\begin{array}{l}\text { General } \\
\text { population }\end{array}$ & Mixed & Mixed & 61 & 40 & $140 / 90$ & 1 & - \\
\hline $\begin{array}{l}\text { Fagard R } \\
2007(23)\end{array}$ & $\begin{array}{c}\text { EU- } \\
\text { countries }\end{array}$ & Community & $\begin{array}{l}\text { General } \\
\text { population }\end{array}$ & Mixed & No $\mathrm{n}$ & 39 & 46.1 & $140 / 90$ & 1 & - \\
\hline $\begin{array}{l}\text { Wang G } \\
2007(24)\end{array}$ & China & Community & $\begin{array}{l}\text { General } \\
\text { population }\end{array}$ & Mixed & Mixed & $\begin{array}{l}(18- \\
86)\end{array}$ & 54.3 & $140 / 90$ & 1 & - \\
\hline $\begin{array}{l}\text { Trudel X } \\
2009(25)\end{array}$ & Canada & Community & $\begin{array}{l}\text { White-collar } \\
\text { workers }\end{array}$ & Non-HT & No & 44 & 38.8 & $140 / 90$ & 1 & - \\
\hline $\begin{array}{l}\text { Ishikawa J. } \\
2010(26)\end{array}$ & Japan & Community & $\begin{array}{l}\text { General } \\
\text { population }\end{array}$ & Mixed & No & 59.9 & 52.7 & $140 / 90$ & 1 & - \\
\hline $\begin{array}{l}\text { Maseko M } \\
\text { 2011(27) }\end{array}$ & $\begin{array}{l}\text { South } \\
\text { Africa }\end{array}$ & Community & $\begin{array}{l}\text { General } \\
\text { population }\end{array}$ & Mixed & Unspecified & 43.9 & 35.6 & $140 / 90$ & 1 & - \\
\hline $\begin{array}{l}\text { Afsar B. } \\
2013(28)\end{array}$ & Turkey & $\begin{array}{l}\text { Health } \\
\text { care }\end{array}$ & Outpatient & Mixed & Unspecified & 57.46 & 67 & $140 / 90$ & 1 & - \\
\hline $\begin{array}{l}\text { Berge H } \\
2013(40)\end{array}$ & Norway & Community & $\begin{array}{l}\text { Male } \\
\text { professional } \\
\text { football } \\
\text { players }\end{array}$ & Mixed & $\begin{array}{c}\text { No } \\
\text { medication }\end{array}$ & 28.1 & - & $140 / 90$ & 1 & - \\
\hline $\begin{array}{l}\text { Alwan H. } \\
\text { 2014(29) }\end{array}$ & Germany & Community & $\begin{array}{l}\text { General } \\
\text { population }\end{array}$ & Mixed & Mixed & 48 & 49 & $140 / 90$ & 1 & - \\
\hline $\begin{array}{l}\text { Conen D. } \\
2014(9)\end{array}$ & $\begin{array}{c}\text { Europe, } \\
\text { South } \\
\text { America } \\
\text { and Asia }\end{array}$ & Community & $\begin{array}{l}\text { General } \\
\text { population }\end{array}$ & Mixed & No & 45.74 & 48.48 & $140 / 90$ & 1 & - \\
\hline $\begin{array}{l}\text { Aihasmi K } \\
2015(30)\end{array}$ & Oman & $\begin{array}{l}\text { Health } \\
\text { care }\end{array}$ & Outpatient & Mixed & Mixed & 46.15 & & $140 / 90$ & - & - \\
\hline $\begin{array}{l}\text { Rhee M } \\
\text { 2015(11) }\end{array}$ & Korea & Community & $\begin{array}{l}\text { General } \\
\text { population }\end{array}$ & Mixed & Unspecified & 46.7 & 35.9 & $140 / 90$ & 1 & - \\
\hline $\begin{array}{l}\text { Mutlu S. } \\
2016(31)\end{array}$ & Turkey & $\begin{array}{l}\text { Health } \\
\text { care }\end{array}$ & $\begin{array}{l}\text { General in- } \\
\text { patient }\end{array}$ & Mixed & Mixed & 44.4 & 54.4 & $140 / 90$ & - & - \\
\hline $\begin{array}{l}\text { Scuteri A. } \\
2016(32)\end{array}$ & Italy & Community & $\begin{array}{l}\text { General } \\
\text { population }\end{array}$ & Mixed & Mixed & 48.93 & 39.88 & $140 / 90$ & - & - \\
\hline $\begin{array}{l}\text { Melgarejo J } \\
\text { 2017(33) }\end{array}$ & $\begin{array}{l}\text { Europe and } \\
\text { Asia }\end{array}$ & Community & $\begin{array}{l}\text { General } \\
\text { population }\end{array}$ & Mixed & No & - & - & $140 / 90$ & 1 & - \\
\hline $\begin{array}{l}\text { Fujita H. } \\
2018(34)\end{array}$ & Japan & Community & $\begin{array}{l}\text { General } \\
\text { population }\end{array}$ & Non-HT & No & - & 51.5 & $140 / 90$ & - & - \\
\hline
\end{tabular}

Studies with complete $2 \times 2$ diagnostic results of HBPM only

\begin{tabular}{|c|c|c|c|c|c|c|c|c|c|c|}
\hline $\begin{array}{l}\text { Almeida A. } \\
2012(58)\end{array}$ & Brazil & $\begin{array}{l}\text { Health } \\
\text { care }\end{array}$ & $\begin{array}{c}\text { General } \\
\text { population }\end{array}$ & Mixed & Mixed & 50.6 & - & $135 / 85$ & - & 5 \\
\hline $\begin{array}{l}\text { Park J. } \\
2017(59)\end{array}$ & Korean & \begin{tabular}{|l|} 
Health \\
care
\end{tabular} & Outpatient & Mixed & Unspecified & 51.8 & 46.5 & $135 / 85$ & - & 6 \\
\hline \multicolumn{11}{|c|}{ Studies with complete $2 \times 2$ diagnostic results of both $C B P M$ and $H B P M$} \\
\hline $\begin{array}{l}\text { Stergiou G } \\
2000(7)\end{array}$ & Greece & $\begin{array}{l}\text { Health } \\
\text { care }\end{array}$ & Outpatient & Mixed & No & 48.4 & 54.9 & $\begin{array}{l}140 / 90 ; \\
140 / 90\end{array}$ & $\begin{array}{c}5 \\
(14-21 \\
\text { days })\end{array}$ & 6 \\
\hline $\begin{array}{l}\text { Hanninen M } \\
\text { 2010(61) }\end{array}$ & Finland & Community & $\begin{array}{l}\text { General } \\
\text { population }\end{array}$ & Mixed & Mixed & 49.1 & 47.9 & $\begin{array}{l}140 / 90 ; \\
135 / 85\end{array}$ & $4(-)$ & 7 \\
\hline $\begin{array}{l}\text { Zhang L } \\
\text { 2015(60) }\end{array}$ & Belgium & $\begin{array}{l}\begin{array}{l}\text { Health } \\
\text { care }\end{array} \\
\end{array}$ & $\begin{array}{l}\text { General } \\
\text { population }\end{array}$ & Mixed & $\begin{array}{l}\text { No } \\
\text { medication } \\
\text { or wash } \\
\text { out period } \\
>2 \text { weeks }\end{array}$ & 50.6 & 51.1 & $\begin{array}{c}140 \\
\text { (SBP); } \\
135 / 85\end{array}$ & $\begin{array}{c}3 \\
\text { (7 days) }\end{array}$ & 7 \\
\hline
\end{tabular}




\begin{tabular}{|c|c|c|c|c|c|c|c|c|c|c|}
\hline $\begin{array}{c}\text { Author } \\
\text { (Year) }\end{array}$ & Country & Setting & $\begin{array}{c}\text { Type of } \\
\text { population }\end{array}$ & $\begin{array}{l}\text { Previous } \\
\text { HT }\end{array}$ & $\begin{array}{c}\text { Taking } \\
\text { anti-HT } \\
\text { drug }\end{array}$ & $\begin{array}{c}\text { Mean } \\
\text { age } \\
\text { (year) }\end{array}$ & \%Male & $\begin{array}{c}\text { CBPM; } \\
\text { HBPM } \\
\text { cut-off } \\
\text { (mmHg) }\end{array}$ & \begin{tabular}{c|} 
No. \\
repeated \\
measure \\
CBPM \\
(day \\
interval) \\
\end{tabular} & $\begin{array}{l}\text { Measurement } \\
\text { duration for } \\
\text { HBPM (day) }\end{array}$ \\
\hline $\begin{array}{l}\text { Hoegholm A. } \\
\text { 1999(35) }\end{array}$ & Denmark & Community & $\begin{array}{l}\text { General } \\
\text { population }\end{array}$ & Mixed & $\begin{array}{c}\text { No } \\
\text { medication } \\
\text { or wash } \\
\text { out period } \\
>5 \text { weeks }\end{array}$ & 47.7 & 46.9 & $140 / 90$ & $\begin{array}{c}3 \\
\text { (7 days) }\end{array}$ & - \\
\hline $\begin{array}{l}\text { Martinez M } \\
1999(36)\end{array}$ & Spain & $\begin{array}{l}\text { Health } \\
\text { care }\end{array}$ & $\begin{array}{l}\text { General } \\
\text { population }\end{array}$ & Non-HT & $\begin{array}{c}\text { No } \\
\text { medication } \\
\text { or wash } \\
\text { out period } \\
>3 \text { weeks }\end{array}$ & 52 & 47.8 & $140 / 90$ & $\begin{array}{c}3 \\
\text { (7-14 } \\
\text { days) }\end{array}$ & - \\
\hline $\begin{array}{l}\text { Gan S } \\
\text { 2003(37) }\end{array}$ & Singapore & Community & $\begin{array}{l}\text { Male } \\
\text { military } \\
\text { conscripts }\end{array}$ & Mixed & Unspecified & 20 & 100 & $140 / 90$ & $\begin{array}{c}2 \\
(14 \\
\text { days) }\end{array}$ & - \\
\hline $\begin{array}{l}\text { Tunckale A. } \\
2004(38)\end{array}$ & Turkey & $\begin{array}{l}\text { Health } \\
\text { care }\end{array}$ & $\begin{array}{l}\text { General } \\
\text { patient }\end{array}$ & Non-HT & $\begin{array}{c}\text { No } \\
\text { medication } \\
\text { or wash } \\
\text { out period } \\
>4 \text { weeks }\end{array}$ & - & - & $140 / 90$ & 3 & - \\
\hline $\begin{array}{l}\text { Shimbo D. } \\
2009 \text { (39) }\end{array}$ & U.S.A. & $\begin{array}{l}\text { Health } \\
\text { care }\end{array}$ & Outpatient & Mixed & $\begin{array}{c}\text { No } \\
\text { medication }\end{array}$ & 52.5 & 46 & $140 / 90$ & $\begin{array}{c}2 \\
(30 \\
\text { days })\end{array}$ & - \\
\hline $\begin{array}{l}\text { Pengkeaw P. } \\
\text { 2014(41) }\end{array}$ & Thailand & $\begin{array}{l}\text { Health } \\
\text { care }\end{array}$ & Outpatient & Mixed & $\begin{array}{c}\text { No } \\
\text { medication } \\
\text { or wash } \\
\text { out period } \\
>4 \text { weeks }\end{array}$ & 42.29 & 74.2 & $140 / 90$ & 1 & - \\
\hline $\begin{array}{l}\text { Mancia } \\
\text { G.2015(42) }\end{array}$ & Italy & Community & $\begin{array}{l}\text { General } \\
\text { population }\end{array}$ & Unspecified & & - & - & $140 / 90$ & $\begin{array}{c}2 \\
(-) \\
\end{array}$ & - \\
\hline \multicolumn{11}{|c|}{ Studies with negative CBPM only } \\
\hline $\begin{array}{l}\text { Schoenthaler } \\
\text { A 2010(43) }\end{array}$ & $\begin{array}{c}\text { U.S. } \\
\text { (African or } \\
\text { Latino) }\end{array}$ & Community & $\begin{array}{l}\text { General } \\
\text { population }\end{array}$ & Mixed & $\begin{array}{c}\text { No } \\
\text { medication }\end{array}$ & 35.9 & 39 & $120 / 80$ & $\begin{array}{c}3 \\
(14 \\
\text { days })\end{array}$ & - \\
\hline $\begin{array}{l}\text { Viera A } \\
2010(44)\end{array}$ & U.S. & Community & $\begin{array}{l}\text { General } \\
\text { population }\end{array}$ & Non-HT & $\begin{array}{c}\text { No } \\
\text { medication }\end{array}$ & 49 & 44 & $140 / 90$ & 1 & - \\
\hline $\begin{array}{l}\text { Bacaksiz A. } \\
2013(45)\end{array}$ & Turkey & $\begin{array}{l}\text { Health } \\
\text { care }\end{array}$ & Outpatient & Non-HT & $\begin{array}{c}\text { No } \\
\text { medication }\end{array}$ & 35.8 & 51.1 & $140 / 90$ & 1 & - \\
\hline $\begin{array}{l}\text { Sobrino J. } \\
2013(46)\end{array}$ & Spain & Community & $\begin{array}{l}\text { General } \\
\text { population }\end{array}$ & Non-HT & $\begin{array}{c}\text { No } \\
\text { medication }\end{array}$ & 43.1 & 44.7 & $140 / 90$ & 1 & - \\
\hline $\begin{array}{l}\text { Franklin S } \\
2013(47)\end{array}$ & $\begin{array}{l}\text { Europe } \\
\text { Japan }\end{array}$ & Community & $\begin{array}{l}\text { General } \\
\text { population }\end{array}$ & Non-HT & Mixed & - & - & $140 / 90$ & 1 & - \\
\hline $\begin{array}{l}\text { Larsen T } \\
2014(48)\end{array}$ & America & $\begin{array}{l}\text { Health } \\
\text { care }\end{array}$ & Outpatient & Non-HT & $\begin{array}{c}\text { No } \\
\text { medication }\end{array}$ & 49.8 & 47 & $140 / 90$ & $3(-)$ & - \\
\hline $\begin{array}{l}\text { Viera A } 2015 \\
\text { (49) }\end{array}$ & America & $\begin{array}{l}\text { Health } \\
\text { care }\end{array}$ & Outpatient & Non-HT & $\begin{array}{c}\text { No } \\
\text { medication }\end{array}$ & 47 & 39 & $140 / 90$ & 1 & - \\
\hline $\begin{array}{l}\text { Trachsel L } \\
2015(50)\end{array}$ & Switzerland & Community & $\begin{array}{l}\text { General } \\
\text { population }\end{array}$ & Non-HT & $\begin{array}{c}\text { No } \\
\text { medication }\end{array}$ & 42.8 & - & $140 / 90$ & 1 & - \\
\hline $\begin{array}{l}\text { Redmond N. } \\
\text { 2016(51) }\end{array}$ & America, & Community & $\begin{array}{l}\text { General } \\
\text { population }\end{array}$ & Mixed & Mixed & 59.1 & 30.7 & $140 / 90$ & 1 & - \\
\hline $\begin{array}{l}\text { Viera A } \\
2016(52)\end{array}$ & America & $\begin{array}{l}\text { Health } \\
\text { care }\end{array}$ & $\begin{array}{l}\text { General } \\
\text { population }\end{array}$ & Non-HT & $\begin{array}{c}\text { No } \\
\text { medication }\end{array}$ & 48 & 40 & $140 / 90$ & 1 & - \\
\hline $\begin{array}{l}\text { Piantanida. } \\
\text { E 2016(53) }\end{array}$ & Italy & $\begin{array}{l}\text { Health } \\
\text { care }\end{array}$ & $\begin{array}{l}\text { General } \\
\text { population }\end{array}$ & Non-HT & $\begin{array}{c}\text { No } \\
\text { medication }\end{array}$ & 46.3 & - & $140 / 90$ & 1 & - \\
\hline $\begin{array}{l}\text { Booth III J } \\
2017(54)\end{array}$ & America & $\begin{array}{l}\text { Health } \\
\text { care }\end{array}$ & Outpatient & Non-HT & $\begin{array}{c}\text { No } \\
\text { medication }\end{array}$ & - & & $140 / 90$ & 1 & - \\
\hline $\begin{array}{l}\text { Anstey D } \\
2017(55)\end{array}$ & America, & Community & $\begin{array}{l}\text { General } \\
\text { population }\end{array}$ & Mixed & Mixed & 56 & 35.7 & $140 / 90$ & 1 & - \\
\hline
\end{tabular}




\begin{tabular}{|l|l|l|l|l|c|c|c|c|c|c}
\hline \multicolumn{1}{|c|}{$\begin{array}{c}\text { Author } \\
\text { (Year) }\end{array}$} & Country & Setting & $\begin{array}{c}\text { Type of } \\
\text { population }\end{array}$ & $\begin{array}{c}\text { Previous } \\
\text { HT }\end{array}$ & $\begin{array}{c}\text { Taking } \\
\text { anti-HT } \\
\text { drug }\end{array}$ & $\begin{array}{c}\text { Mean } \\
\text { age } \\
\text { (year) }\end{array}$ & $\begin{array}{c}\text { \%Male } \\
\text { CBPM; }\end{array}$ & $\begin{array}{c}\text { No. } \\
\text { HBPM } \\
\text { cut-off } \\
\text { (mmHg) } \\
\text { repeated } \\
\text { measure } \\
\text { CBPM } \\
\text { (day } \\
\text { interval) }\end{array}$ & $\begin{array}{c}\text { Measurement } \\
\text { duration for } \\
\text { HBPM (day) }\end{array}$ \\
\hline $\begin{array}{l}\text { Ozkan S. } \\
\text { 2018(56) }\end{array}$ & Turkey & $\begin{array}{l}\text { Health } \\
\text { care }\end{array}$ & Outpatient & Non-HT & $\begin{array}{c}\text { No } \\
\text { medication }\end{array}$ & 58.8 & 25.1 & $140 / 90$ & - & - \\
\hline $\begin{array}{l}\text { Gun T. } \\
2018(57)\end{array}$ & Turkey & $\begin{array}{l}\text { Health } \\
\text { care }\end{array}$ & Outpatient & Non-HT & $\begin{array}{c}\text { No } \\
\text { medication }\end{array}$ & 55 & 46.5 & - & 1 & \\
\hline
\end{tabular}

ABPM; ambulatory blood pressure measurement, CBPM; clinic blood pressure measurement, DBP; diastolic blood pressure, HBPM; home blood pressure measurement, HT; hypertension, SBP; systolic blood pressure

\section{Figures}

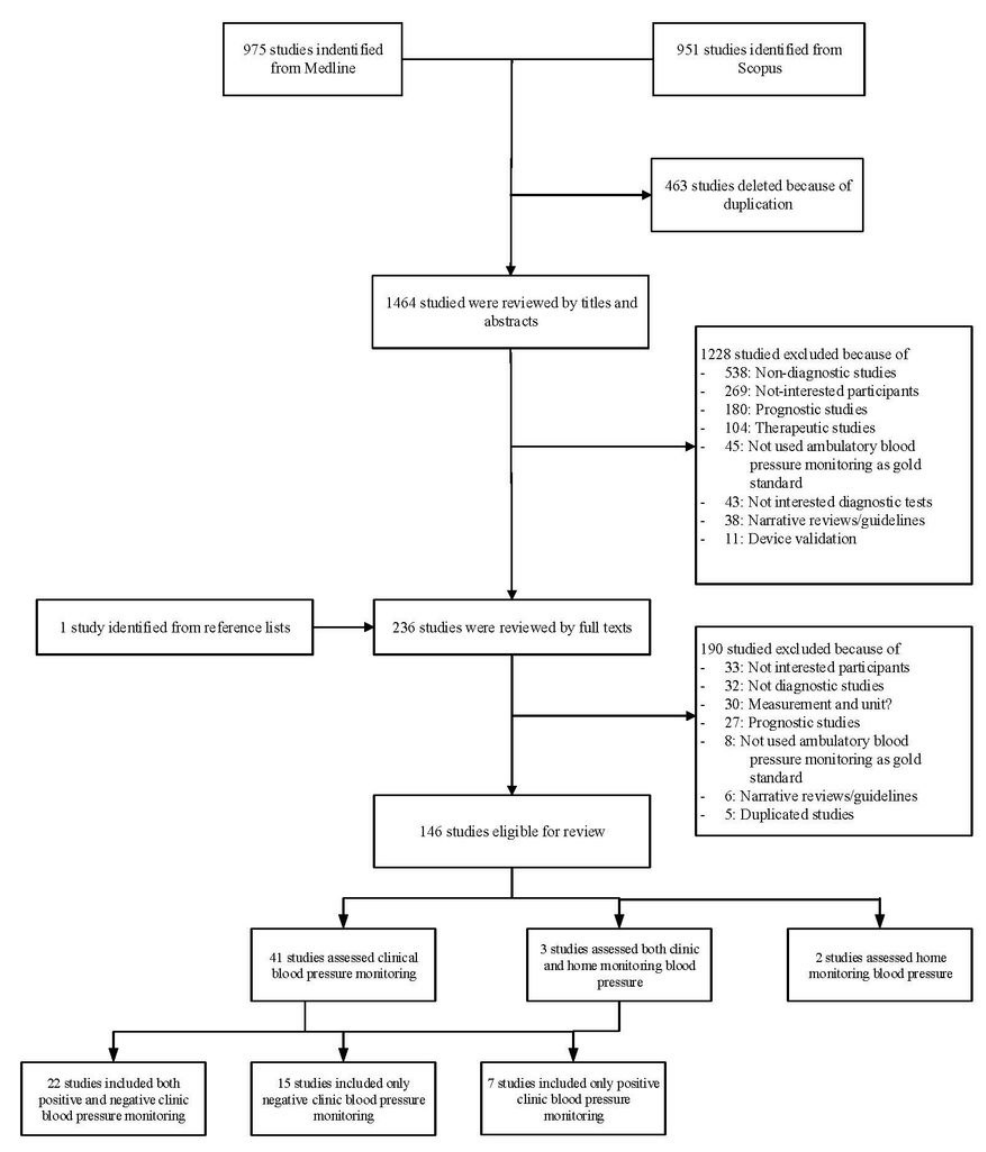

Figure 1

Flow chart of study selection 
a) Pooled sensitivity of CBPM

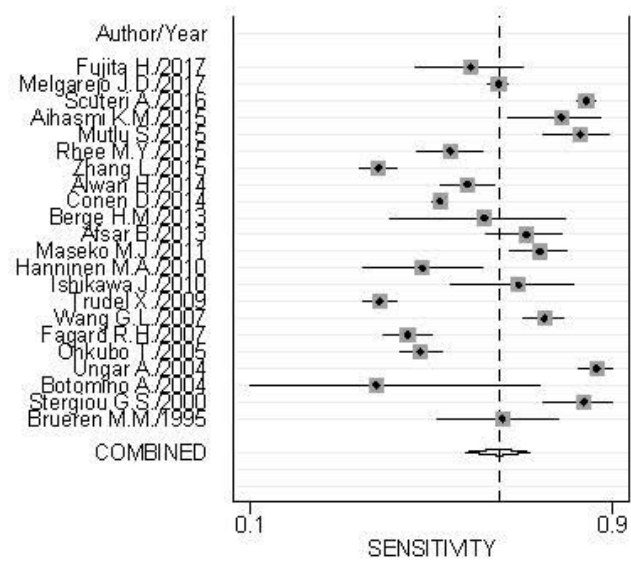

c) Pooled sensitivity of HBPM

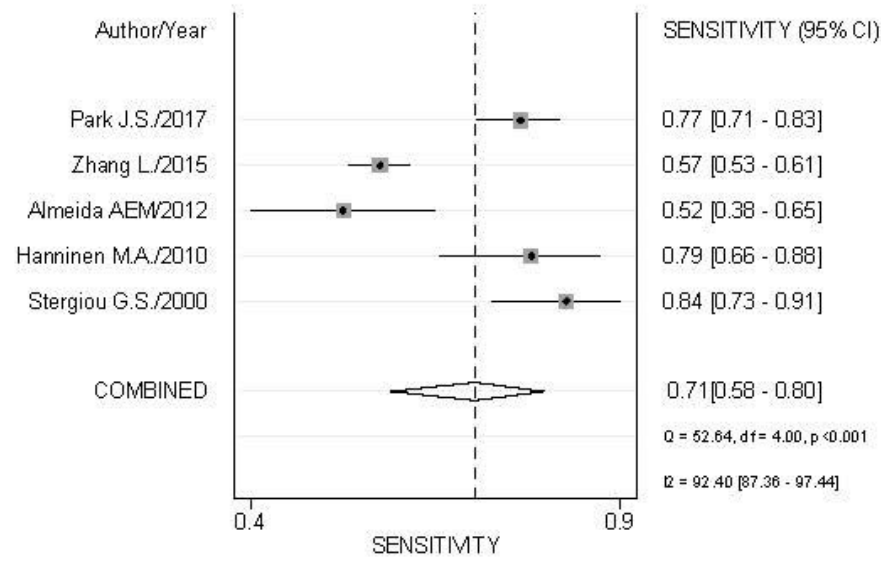

b) Pooled specificity of CBPM
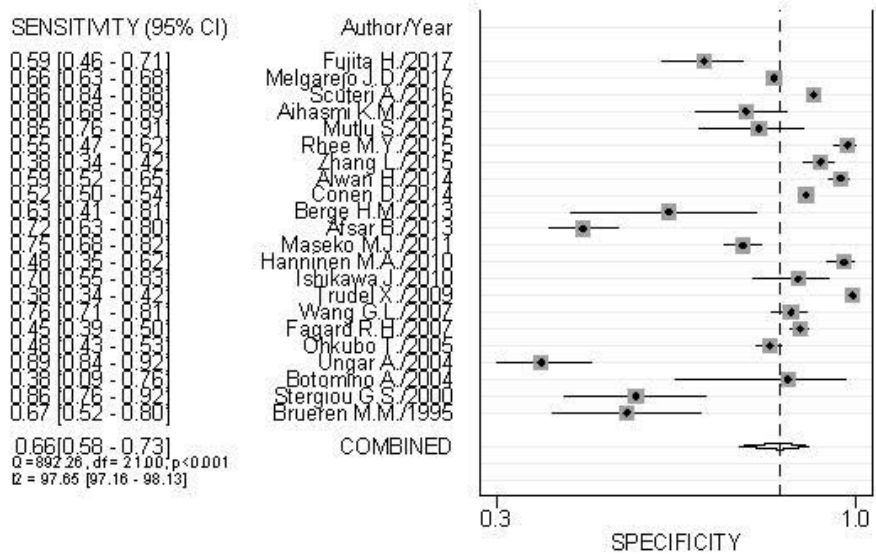

SPECIFICITY $(95 \% \mathrm{Cl})$

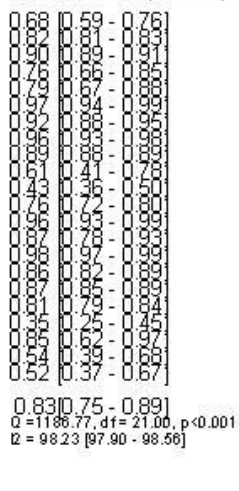

d) Pooled specificity of HBPM

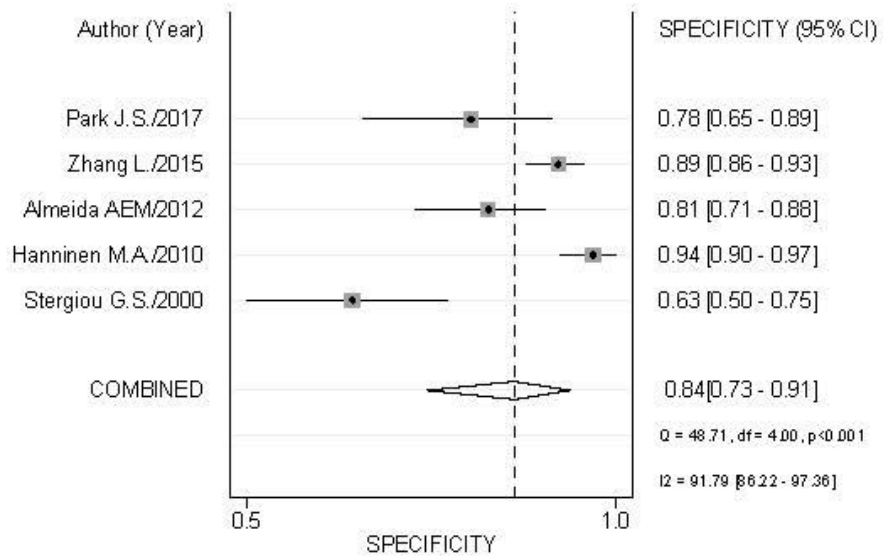

\section{Figure 2}

Pooled sensitivity and specificity of clinic and home blood pressure measurements compared with ambulatory blood pressure measurement 
a) CBPM
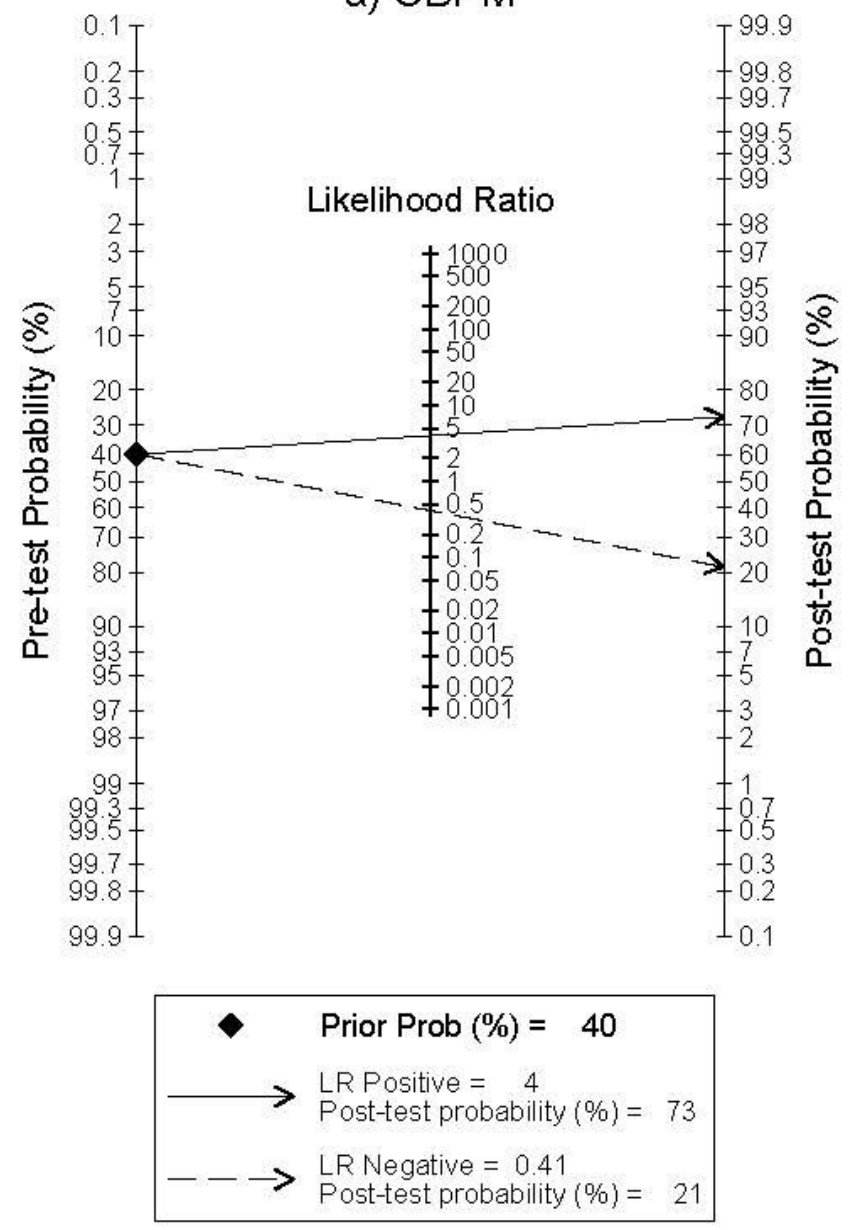

b) HBPM
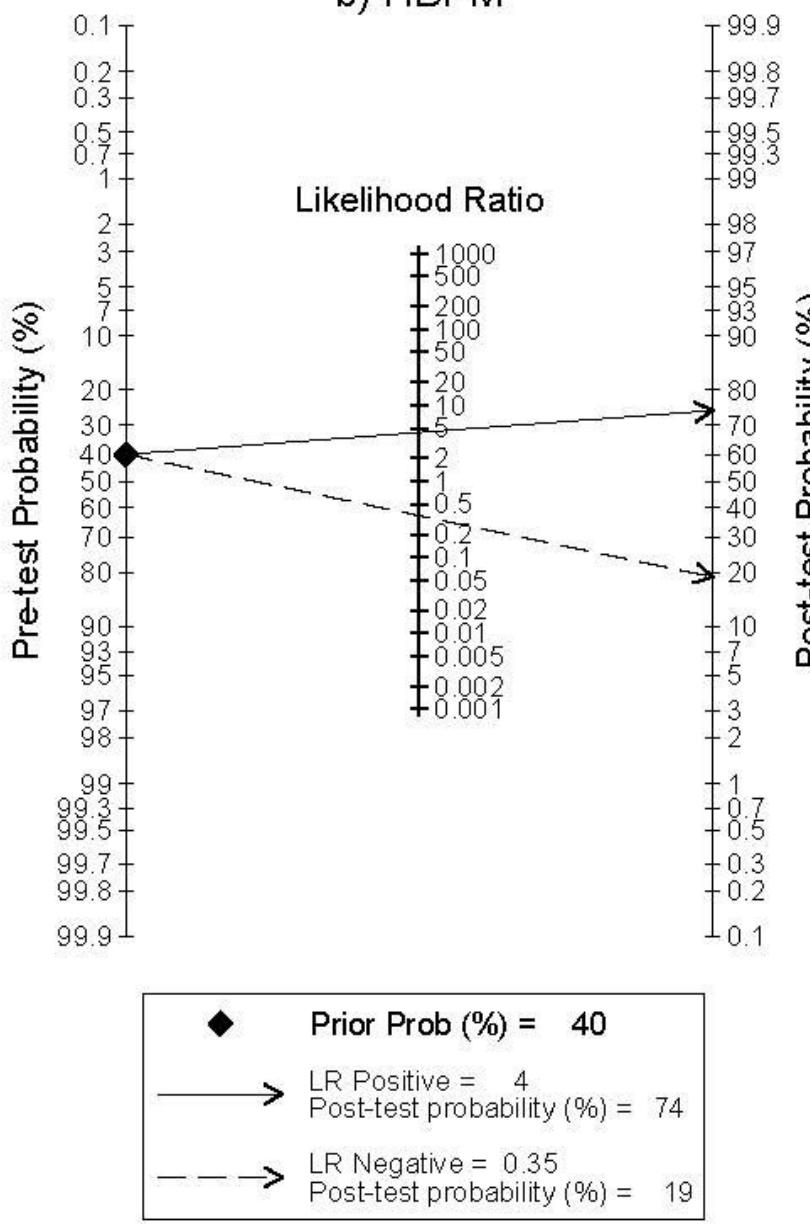

Figure 3

Fagan's plot of clinic and home blood pressure measurements compared with ambulatory blood pressure measurement 
a) White coat HT among positive CBPM

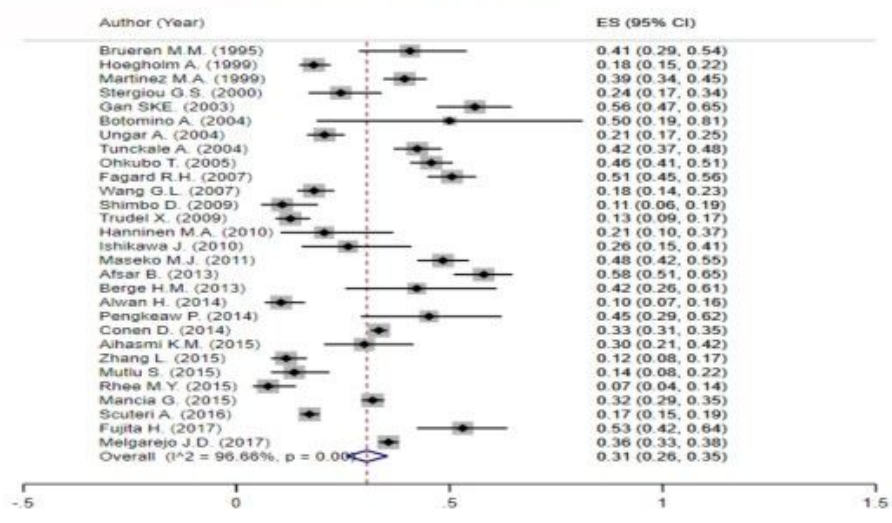

c) White coat HT among positive HBPM

b) Masked HT among negative CBPM

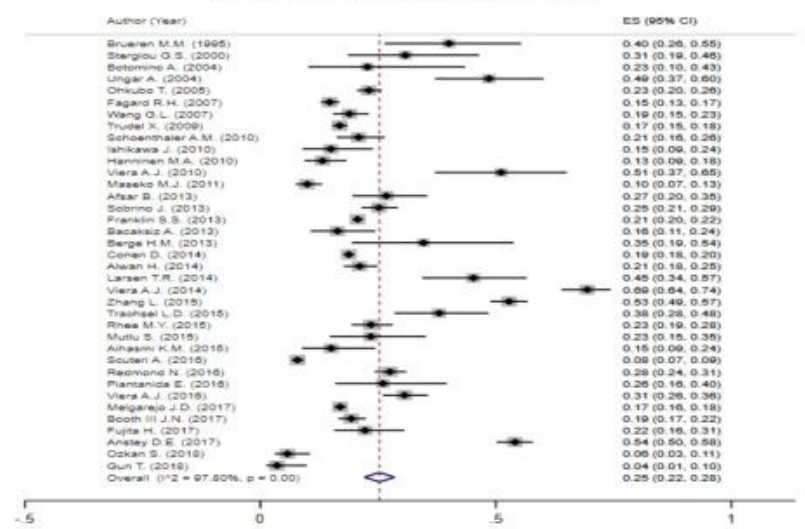

d) Masked HT among negative HBPM

ES $(95 \% \mathrm{Cl})$

Author (Year)

ES $(95 \% \mathrm{Cl})$

$0.27(0.18,0.37)$

$0.21(0.13,0.34)$

$0.38(0.26,0.52)$

$0.10(0.07,0.14)$

$0.07(0.04,0.11)$

$0.19(0.10,0.27)$

Overall $\left(1^{\wedge} 2=88.65 \%, p<0.001\right)$
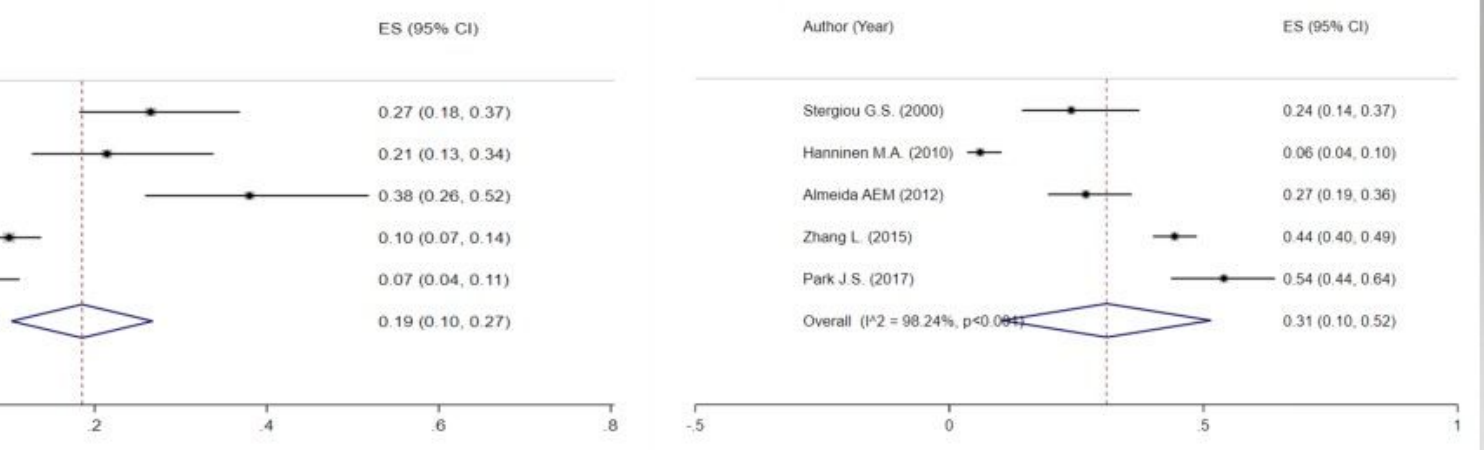

Figure 4

Pooled proportion of white coat hypertension among positive clinic/home blood pressure measurements and masked hypertension among negative clinic/home blood pressure measurements

\section{Supplementary Files}

This is a list of supplementary files associated with this preprint. Click to download.

- Additionalfile.docx 